\title{
Copper chelation and interleukin- 6 proinflammatory cytokine effects on expression of different proteins involved in iron metabolism in HepG2 cell line
}

\author{
Luca Marco Di Bella ${ }^{1,2}$, Roberto Alampi ${ }^{1}$, Flavia Biundo ${ }^{1}$, Giovanni Toscano ${ }^{1}$ and Maria Rosa Felice ${ }^{1 *}$ (D)
}

\begin{abstract}
Background: In vertebrates, there is an intimate relationship between copper and iron homeostasis. Copper deficiency, which leads to a defect in ceruloplasmin enzymatic activity, has a strong effect on iron homeostasis resulting in cellular iron retention. Much is known about the mechanisms underlying cellular iron retention under "normal" conditions, however, less is known about the effect of copper deficiency during inflammation.

Results: We show that copper deficiency and the inflammatory cytokine interleukin-6 have different effects on the expression of proteins involved in iron and copper metabolism such as the soluble and glycosylphosphtidylinositol anchored forms of ceruloplasmin, hepcidin, ferroportin 1, transferrin receptor1, divalent metal transporter1 and H-ferritin subunit. We demonstrate, using the human HepG2 cell line, that in addition to ceruloplasmin isoforms, copper deficiency affects other proteins, some posttranslationally and some at the transcriptional level. The addition of interleukin-6, moreover, has different effects on expression of ferroportin1 and ceruloplasmin, in which ferroportin 1 is decreased while ceruloplasmin is increased. These effects are stronger when a copper chelating agent and IL-6 are used simultaneously.
\end{abstract}

Conclusions: These results suggest that copper chelation has effects not only on ceruloplasmin but also on other proteins involved in iron metabolism, sometimes at the mRNA level and, in inflammatory conditions, the functions of ferroportin and ceruloplasmin may be independent.

Keywords: Iron metabolism, Copper deficiency, Inflammation, Ceruloplasmin

\section{Background}

Iron and copper are cofactors for numerous enzymes and are essential elements for all eukaryotes. They are, however, potentially dangerous because they can react with molecular oxygen generating reactive oxygen species that will damage DNA, lipids and proteins [1-3], and because they are both essential and dangerous their levels are strictly regulated. The copper-containing protein ceruloplasmin has an essential role in iron homeostasis. Its catalytic site has six copper atoms, four of which are involved in iron oxidation [4-6], converting $\mathrm{Fe}^{2+}$ to $\mathrm{Fe}^{3+}$ without generating reactive oxygen species.

\footnotetext{
* Correspondence: mrfelice@unime.it

'Department of Chemical, Biological, Pharmaceutical, and Environmental Sciences, University of Messina, Viale F. Stagno D'Alcontres, 31, 98166 Messina, Italy

Full list of author information is available at the end of the article
}

In vertebrates, two forms of ceruloplasmin are expressed; the first is mainly produced by hepatocytes and is secreted into the circulation [7-9]. A second form, which is generated by alternative splicing, contains a glycosylphosphatidylinositol (GPI) moiety instead of the normal carboxyl terminal. The GPI anchors ceruloplasmin in the plasma membrane. GPI-Cp was found first in astrocytes where it represents the principal ferroxidase $[10,11]$. GPI-Cp, however, is expressed by other cellular types such as leptomeningeal cells, Sertoli cells, and hepatocytes [12-15]. Another important ferroxidase is hephaestin, a transmembrane protein first detected in the small intestine [16, 17]. It mediates iron export from enterocytes to the bloodstream. Hephaestin and the two different forms of ceruloplasmin are suggested to interact with ferroportin, the only known protein involved in ferrous iron export 
from the cells [18-22]. $\mathrm{Fe}^{3+}$ generated by ferroxidase activity, is loaded onto transferrin (Tf), the major ironcontaining protein involved in plasma iron transport and distribution within organisms [23-25]. Diferric Tf binds to transferrin receptor 1 (TfR1) present on the plasma membrane of most cell types and in particular on developing red blood cells [26]. Once bound, the $\operatorname{Tf}(\mathrm{Fe})_{2}$-TfR1 complex is internalized into an endosome where iron is released from Tf and is then exported to the cytoplasm by divalent metal transporter 1 protein (DMT1) [27-29]. The importance of ceruloplasmin in iron metabolism is demonstrated by the fact that decreases in active ceruloplasmin, as seen in Wilson or Menkes disease, is characterized by a strong accumulation of iron in liver, spleen, and brain [30-34]. Moreover, different studies have highlighted the importance of ceruloplasmin and iron metabolism in pathologies like Alzheimer and Parkinson diseases [35-38].

Systemic iron homeostasis is regulated by different stimuli and, in particular, inflammation can affect the concentration and accumulation of iron in the serum and in different organs [39]. Hepatocytes play a critical role in cellular iron as they are the major storage site for excess iron and are a central regulator of proteins (transferrin, ceruloplasmin and hepcidin) that play an important role in iron homeostasis. In particular, hepatocytes are the principal producers of the secreted peptide hormone, hepcidin. Hepcidin, by binding to the iron exporter ferroportin (Fpn1), induces its degradation resulting in reduced iron uptake from the diet and iron efflux from macrophages [40-42]. Hepcidin mRNA expression is increased by inflammatory cytokines [43, 44]. In particular, IL-6, a proinflammatory cytokine, induces the synthesis of hepcidin and it is responsible of a state of hypoferremia of inflammation [44, 45]. Pro-inflammatory cytokines can also regulate expression of other proteins involved in iron metabolism such as Fpn1, DMT1, TfR1 and ceruloplasmin [46-50].

Although studies have highlighted the effect exerted by copper deprivation or pro-inflammatory cytokines on expression of proteins involved in iron metabolism separately, it is not known if there is a synergistic effect of copper depletion and inflammation. The aim of this study was to analyse the effect of copper chelation and the pro-inflammatory cytokine interleukin-6 (IL-6) on the mRNA and protein levels of different proteins involved in iron metabolism using the human hepatocytoma cell line HepG2 as a model system.

\section{Methods}

\section{Cell culture and treatment}

The hepatocytoma cell line HepG2, kindly provided by prof. M.T. Sciortino (Department of Chemical, Biological, Pharmaceutical and Environmental Sciences, University of
Messina, Italy), was grown in Eagle's minimum essential medium (EMEM) (Lonza) supplemented with 10\% Fetal Bovine Serum (Lonza), $1 \times$ non-essential amino acids (Lonza), $2 \mathrm{mM}$ L-glutamine (Lonza), $100 \mu \mathrm{g} / \mathrm{ml}$ Streptomycin (Sigma), $100 \mathrm{U} / \mathrm{ml}$ Penicillin (Sigma), at $37^{\circ} \mathrm{C}$, and $5 \% \mathrm{CO}_{2} .4 \times 10^{5}$ cells $/ \mathrm{ml}$ were seeded in 6 well plates and incubated for $24 \mathrm{~h}$ in supplemented medium. Before treatment, cells were washed with PBS and incubated for an additional $16 \mathrm{~h}$ in serum-free, antibiotic-free medium, in the presence of $40 \mathrm{ng} / \mathrm{ml}$ of IL-6 (Cell Signaling Technology) [51] and/or $300 \mu \mathrm{M}$ Bathophenanthroline disulfonate (BCS) (Sigma).

\section{RT-PCR analysis}

Total RNA was extracted by EuroGold TriFast reagent (Euroclone) following the manufacturer's instructions. The concentration and purity of RNA was assayed at $260 \mathrm{~nm}$ and $280 \mathrm{~nm}$ by a DU 60 Beckman spectrophotometer. One $\mu \mathrm{g}$ of total RNA was retro-transcribed using oligo-dT (EuroClone) and PrimeScript MMLV-RT (Takara, Clontech) at $42{ }^{\circ} \mathrm{C}$ for $60 \mathrm{~min}$ followed by a denaturation step of $15 \mathrm{~min}$ at $70{ }^{\circ} \mathrm{C}$. The primers used for PCR are listed in Table 1. The PCR reactions were run for 30 cycles in MyCycler instruments (BioRad) using EmeraldAmp Hot start DNA polymerase (Takara,

Table 1 list of primers used in this study

\begin{tabular}{|c|c|c|}
\hline primer & Sequence $5^{\prime} \rightarrow 3^{\prime}$ & Reference \\
\hline Fpn1AB Reverse & CATCCTCTCTGGCGGTTGTG & This study \\
\hline Fpn1A Forward & TCCATAAGGCTTTGCCTTTCC & This study \\
\hline Fpn1B Forward & GCATCTGGTTGGAGTITCAAT & This study \\
\hline GPI-Cp Reverse & GATTGGGTAGATCACATTCC & [90] \\
\hline sCp Reverse & CCAATTTATTTCATTCAGCC & {$[90]$} \\
\hline CP Forward & GTCTITGACCTTATCCCTGG & This study \\
\hline HAMP Forward & ATGGCACTGAGCTCCCAGAT & This study \\
\hline HAMP Reverse & TTGCAGCACATCCCACACTIT & This study \\
\hline$\beta$-actin Reverse & CACATCTGCTGGAAGGTGGA & This study \\
\hline \multirow[t]{2}{*}{$\beta$-actin Forward } & CATGAAGTGCGACGTTGACA & This study \\
\hline & qPCR Primers & \\
\hline TNF-a Forward & GCAGGTCTACTITGGGATCATTG & $\begin{array}{l}\text { A generous gift } \\
\text { of prof. A. Mastino }\end{array}$ \\
\hline TNF-a Reverse & GCGTTTGGGAAGGTTGGA & $\begin{array}{l}\text { A generous gift } \\
\text { of prof. A. Mastino }\end{array}$ \\
\hline IL1B Forward & GCGAATGACAGAGGGTTTCTTAG & $\begin{array}{l}\text { A generous gift } \\
\text { of prof. A. Mastino }\end{array}$ \\
\hline IL1B Reverse & CACCTTCAGCTGCCCAGACT & $\begin{array}{l}\text { A generous gift } \\
\text { of prof. A. Mastino }\end{array}$ \\
\hline$\beta$-actin Forward & CATTCCAAATATGAGATGCGTTGT & This study \\
\hline$\beta$-actin Reverse & TGTGGACTTGGGAGAGGACT & This study \\
\hline
\end{tabular}

${ }^{a}$ Department of Chemical Biological Pharmaceutical and Environmental Sciences, University of Messina, Italy 
Clontech). The PCR conditions adopted were: $98{ }^{\circ} \mathrm{C}$ for $10 \mathrm{~s}, 57^{\circ} \mathrm{C}$ for $1 \mathrm{~min}, 72{ }^{\circ} \mathrm{C}$ for $30 \mathrm{~s}$. The PCR amplicons were analyzed by $2.4 \%$ agarose gel electrophoresis, and images were acquired by KdS1D system (Kodak) and analyzed by ImageJ 1.47v software (http://imagej.nih.gov/ij). All the intensity values obtained for genes of interest were normalized with respect to $\beta$-actin.

Quantitative Real Time PCR, was performed on the same cDNA using StepOne Plus (Applied Biosystem, LifeTechnologies) and Sybr Premix Ex Taq II (Takara, Clontech) following manufacturer's instructions and primers listed in Table 1 . The amplification was performed at $95{ }^{\circ} \mathrm{C}$ for $30 \mathrm{~s}$ ( 1 cycle), $95{ }^{\circ} \mathrm{C}$ for $5 \mathrm{~s}$ and $60{ }^{\circ} \mathrm{C}$ for $60 \mathrm{~s}$ (40 cycles). All samples were assayed in duplicate of three independent experiments and the results were normalized to the $\beta$-actin housekeeping gene using $\Delta \Delta C_{T}$ method [52, 53].

\section{Protein extraction and Western blot analysis}

To analyze proteins, after specific incubations, cells were washed with PBS and then homogenized in specified lysis buffers. The specific buffer used differed depending on the protein being assayed. For immunodetection of DMT1, H-ferritin subunit, STAT3 and pSTAT3 the lysis buffer was composed of $25 \mathrm{mM}$ MOPS pH 7.4 (Sigma), $150 \mathrm{mM} \mathrm{NaCl}$ (Applichem), 1\% Triton X-100 (Sigma), and protease inhibitor cocktail (Sigma). The cells were homogenized by passage through a 28 gauge needle several times and left one hour at room temperature, before centrifugation at $15,400 \times \mathrm{g}$ for $30 \mathrm{~min}$ at $4{ }^{\circ} \mathrm{C}$ (Eppendorf $3417 \mathrm{R})$. Total protein concentration of supernatant was assayed by BCA (Pierce) and an equal quantity of total proteins were analyzed by polyacrylamide gel electrophoresis using $16.5 \%$ Tris-Tricine SDS-PAGE for DMT1 and FTH1 [54], or 10\% SDS-PAGE for STAT3 and pSTAT3, after denaturation at $95{ }^{\circ} \mathrm{C}$ for $10 \mathrm{~min}$ in the presence of $80 \mathrm{mM}$ Dithiothreitol (DTT). For immunodetection of TfR1 and GPI-Cp cells were homogenized in a buffer composed of 25 mM MOPS pH 7.4 (Sigma), $75 \mathrm{mM} \mathrm{NaCl}$ (Applichem), and protease inhibitor cocktail (Sigma) by passage through a 28 gauge needle several times. The homogenate was centrifuged at 15,400 $\times \mathrm{g}$ for $30 \mathrm{~min}$ at $4{ }^{\circ} \mathrm{C}$ and the pellet was incubated in extraction buffer composed of $25 \mathrm{mM}$ MOPS $\mathrm{pH} 7.4$, $150 \mathrm{mM} \mathrm{NaCl}$ (Sigma), 1\% Triton X-100 (Sigma), and protease inhibitor cocktail (Sigma) for one hour before centrifugation as described above. Total protein concentration was assayed by BCA and equal quantities of total protein were separated by $10 \%$ Tris-Glycine SDS-PAGE after denaturation at $95{ }^{\circ} \mathrm{C}$ for $10 \mathrm{~min}$ in the presence of $80 \mathrm{mM}$ DTT. The same membrane protein extraction protocol was used for Fpn1 with the exception that samples were incubated for $30 \mathrm{~min}$ at room temperature in the presence of $80 \mathrm{mM}$ DTT before separation on $10 \%$ Tris-Glycine SDS-PAGE $[55,56]$.

After electrophoresis proteins were transferred to FluoroTransW PVDF Membrane (Pall Corporation) by MiniTrans Blot (BioRad) and membranes were blocked with 5\% skim milk (Applichem) before incubation overnight with primary antibodies that are listed in Table 2. After washing, the membranes were incubated with HRPconjugated secondary antibodies and proteins were detected by etaC Westar ECL (Cyagen). The bands were analyzed by ImageJ $1.47 \mathrm{v}$ software (http://imagej.nih.gov/ij). The intensity values obtained for proteins of interest were normalized with respect to $\beta$-actin protein level.

\section{Cellular copper and iron concentration}

Total cellular homogenates were obtained as described in section 2.3. For copper and iron mineralization, the homogenate was digested with 1:1 volume ratio of $65 \%$ $\mathrm{HNO}_{3}$ overnight at $60{ }^{\circ} \mathrm{C}$ [57].

After a dilution of $\mathrm{HNO}_{3}$ to $5 \%$, equal aliquots of samples were used for copper and iron determination by a graphite furnace Perkin Elmer PinAACle $900 \mathrm{H}$ atomic absorption spectrophotometer, equipped with the autosampler AS900 and the Lumina cathode lamp (Perkin Elmer). Calibration was against a $\mathrm{Cu}$ or a Fe standard curve and the metal content was normalized to total cellular proteins concentration, determined by BCA assay kit, as described in section 2.3.

\section{Immunodetection and in-gel oxidase activity of secreted Ceruloplasmin}

After specific treatments of cells, the medium was collected, concentrated, dialyzed by Centricon YM-50 (Millipore), and proteins were separated by $8 \%$ SDSPAGE in non-denaturing condition for assay of oxidase

Table 2 list of antibodies used in this study

\begin{tabular}{llll}
\hline Target & Dilution & Host & Company \\
\hline Fpn1 & $1: 1,000$ & Rabbit & Novus Biologicals \\
DMT1 & $1: 1,000$ & Mouse & Novus Biologicals \\
TfR1 & $1: 5,000$ & Mouse & Invitrogen \\
pSTAT3 & $1: 1,000$ & Rabbit & Cell Signalling \\
STAT3 & $1: 1,000$ & Rabbit & Cell Signalling \\
FTH1 & $1: 1,000$ & Rabbit & Cell Signalling \\
Human Ceruloplasmin & $1: 5,000$ & Goat & Sigma \\
B-Actin & $1: 10,000$ & Mouse & Sigma \\
Anti-goat HRP conjugated & $1: 4,000$ & Rabbit & Sigma \\
Anti-mouse HRP conjugated & $1: 5,000$ & Goat & Novex, ThermoFisher \\
Anti-rabbit HRP conjugated & $1: 4,000$ & Goat & Novex, ThermoFisher \\
\hline
\end{tabular}


activity. To assay oxidase activity, gels were incubated in $0.1 \mathrm{M}$ sodium acetate buffer $\mathrm{pH} 5.0$ containing $0.5 \mu \mathrm{g} / \mathrm{ml}$ of o-dianisidine dihydrochloride (Sigma) [58]. Alternatively, samples were incubated under reducing conditions for Western blot analysis and immunodetection (as described above) or gels were stained with Coomassie Blue.

\section{Statistical analysis}

The data were analyzed by GraphPad Prism 5.0. Values are expressed as the mean \pm SEM. All assays were performed with samples obtained from six independent experiments. Statistical differences were determined by paired Student's $t$-test. Differences were considered significant at $p<0.05$ level.

\section{Results}

\section{Analysis of Signal Transducer and Activator of} Transcription 3 (STAT3) transcription factor

It is known that interleukin-6 is able to induce the phosphorylation and nuclear translocation of the transcription factor STAT3 $[59,60]$. The level of pSTAT3 was analysed to verify if the concentration of IL- 6 and the period of treatment adopted in the present study were able to evoke a response in the HepG2 cell line. A concentration of $40 \mathrm{ng} / \mathrm{ml} \mathrm{IL-6}$ was able to activate STAT3 and the presence of BCS did not affect STAT3 phosphorylation state in control cells or IL-6 treated cells (Fig. 1a).
Effects of BCS and IL- 6 on expression of secreted form of ceruloplasmin and determination of cellular copper concentration

The capacity of BCS to copper deprive cells was investigated by the analysis of the secreted form of ceruloplasmin (Cp), as copper deficiency is known to result in secretion of apoCp that is rapidly turned over [61]. Incubation of HepG2 cells with BCS results in the of loss Cp oxidase activity and immunodetectable Cp (Fig. 1b). IL-6 treatment is able to induce a strong signal of $\mathrm{Cp}$ protein with respect to control conditions, yet incubation with $\mathrm{BCS}$ results in the disappearance of $\mathrm{Cp}$ from the medium. A densitometric analysis comparison highlighted a strong correlation between soluble $\mathrm{Cp}$ oxidase activity and immunoreactivity (Fig. 1c). $C p$ mRNA levels were measured to determine if the decrease in Çp protein resulted from a decrease in $C p$ mRNA. Incubation with BCS resulted in a slight but statistically significant decrement of $C p$ mRNA compared to control conditions (Figs. 1d, and e). In contrast, treatment with IL-6 caused a threefold induction of $C p$ mRNA that was only slightly reduced by incubation with BCS, indicating that the absence of $\mathrm{Cp}$ in the media of cells treated with BCS was largely due to either a slower rate of protein secretion or degradation of the apo form of secreted $\mathrm{Cp}$ and was not the result of downregulation of gene expression.

To exclude a secondary effect exerted by BCS that is independent of copper deficiency, we have determined by atomic absorption copper intracellular concentration
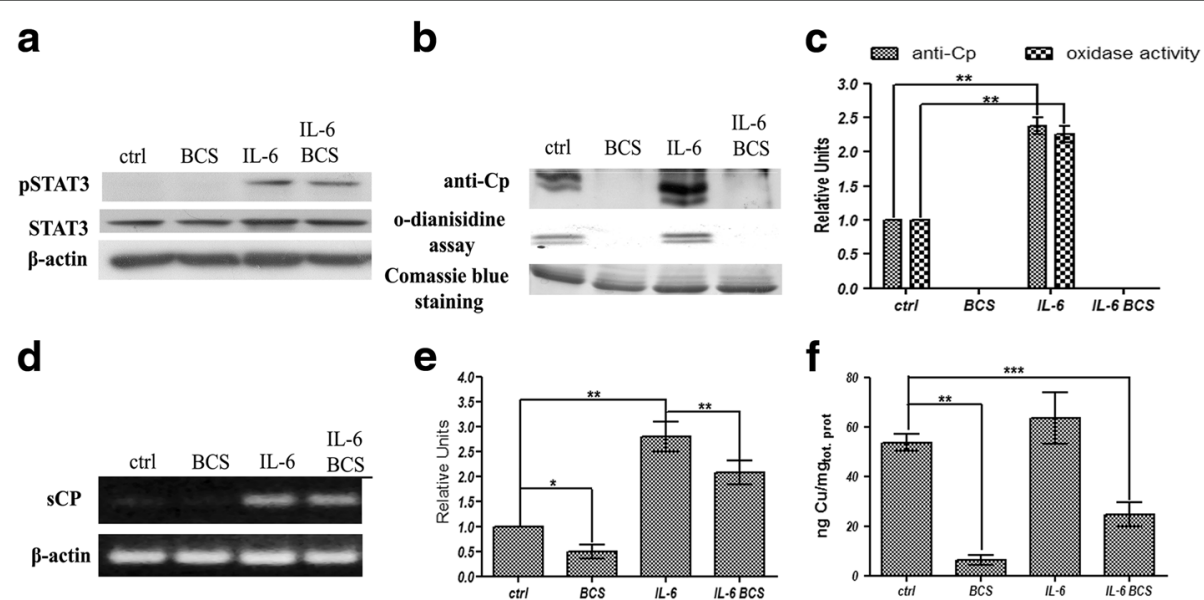

Fig. 1 Western blot and RT-PCR analysis. HepG2 cells were treated for $16 \mathrm{~h}$ in serum-free medium with $300 \mu \mathrm{M}$ BCS and/or $40 \mathrm{ng} / \mathrm{ml}$ of IL-6. a Western blot analysis of pSTAT3, STAT3, and $\beta$-actin proteins on total cell extracts as described in methods. $\mathbf{b}$ Western blot, Coomassie Blue staining of soluble Cp isoform, relative to denaturing SDS-PAGE, and in gel nondenaturing SDS-PAGE enzymatic activity of concentrated and dialyzed culture medium. Equal amounts of total proteins were loaded per lane. $\mathbf{c}$ relative densitometric analysis. $\mathbf{d}$ representative image of soluble CP isoform RT-PCR product: after $16 \mathrm{~h}$ of treatment, RNA was isolated, reverse transcribed and subjected to PCR. The amplicons relative to soluble $C p$ isoform and $\beta$-actin were analysed by agarose gel electrophoresis and intensity of bands was determined by Image 1.47v software (http://imagej.nih.gov/ij). The values of intensity relative to soluble Cp were normalized by using the $\beta$-actin housekeeping gene, (e) densitometric analysis of Cp RT-PCR results. $\mathbf{f}$ graph relative to intracellular copper concentration in HepG2 cells. Cells were extensively washed, lysed as described in methods and used for atomic absorption analysis. The copper content was normalized by cellular total protein concentration. All values are expressed as means $\pm \operatorname{SEM}(n=6)$. All indicated differences were statistically significant $(p<0.05) .{ }^{*} p \leq 0.05 ;{ }^{* *} p \leq 0.01 ;{ }^{* * *} p \leq 0.001$. Expression levels of control condition were normalized to one, and all values are expressed as relative units 
and, in accord with the results reported above, the treatment of HepG2 cells with BCS induces a strong decrement of copper content and the cotreatment with IL-6 has only a slight positive effect (Fig. 1f).

\section{Effects of BCS and IL- 6 on expression of GPI-anchored form of ceruloplasmin}

In addition to the secreted form of $\mathrm{Cp}$, hepatocytes express GPI-anchored Cp [15]. The effect of BCS alone or in combination with IL-6 on the GPI-anchored Cp was also investigated. At the transcriptional level (Fig. 2a and b), IL-6 induced a strong induction in GPI-CP mRNA level compared to control cells. Treatment with BCS did not affect transcription in either control cells or in the IL-6 treated cells, indicating a behaviour very similar to that observed for expression of secreted Cp. The presence of BCS did not affect the amount of GPI$\mathrm{Cp}$ present at the plasma membrane (Fig. 2c, and d). Unfortunately, the level of GPI-Cp was too low to assess enzymatic activity.

\section{Effect of BCS on HAMP and Fpn1 expression}

Studies have shown a functional relationship between $\mathrm{Cp}$ and Fpn1 in which $\mathrm{Cp}$ is required to convert Fpn1exported $\mathrm{Fe}^{2+}$ to $\mathrm{Fe}^{3+}$ for binding to Tf. Some studies have shown a physical relationship between GPI-Cp and Fpn1 $[62,63]$. Based on these results we examined the effects of BCS and IL-6 on Fpn1 and HAMP, the hepcidin gene. IL-6 was able to induce transcription of HAMP as previously reported [44], while the presence of BCS did not affect its expression level (Fig. 3a, and b). These results show the effect of $\mathrm{BCS}$ is specific for $C p$ expression but not for HAMP expression.

At the transcriptional level, expression of the two spliced variant forms of Fpn1, $1 A$ and $1 B$ [64, 65] (Fig. 3c, $d$, e, and $f$ ) were both decreased by BCS or IL-6. BCS had a similar effect on both isoforms while the negative effect of IL-6 is less evident in variant $1 A(50 \%)$ versus variant 1B (30\%) (Fig. 3d, and f). Incubation of HepG2 cells with both IL- 6 and BCS resulted in a small additive decrease, however, it did not reach statistical significance. A difference in the amount of Fpn1 protein was also observed when cells were treated with BCS or IL-6 (Fig. 3g, and h). Fpn1 levels were decreased 50 or $30 \%$ respectively. Further, incubation with BCS and IL-6 resulted in an additional protein decrement, which was statistically significant, indicating an additive effect of the two substrates. These experimental results highlight that the effect of this pro-inflammatory cytokine and copper chelation can negatively regulate Fpn1 expression.
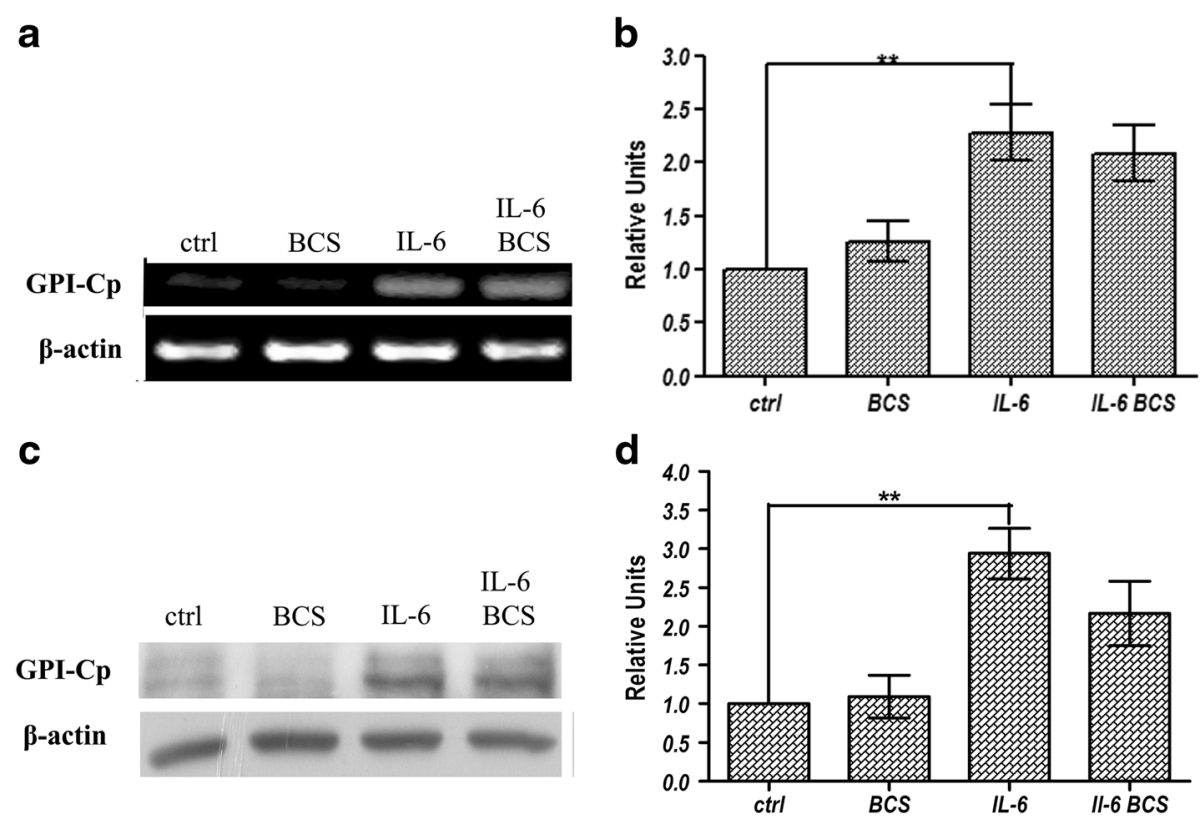

Fig. 2 RT-PCR and Western blot analysis of GPI-Cp expression levels. HepG2 cells were treated for $16 \mathrm{~h}$ in serum-free medium with $300 \mu \mathrm{M}$ BCS

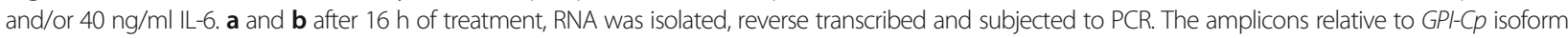
and $\beta$-actin were analysed by agarose gel electrophoresis and intensity of bands was determined by ImageJ 1.47v software (http://imagej.nih.gov/ij). The values of intensity relative to GPI-Cp were normalized by using the $\beta$-actin housekeeping gene. c representative image of GPI-Cp isoform protein relative to membrane proteins extracts analysed by western blot. $\mathbf{d}$ densitometric analysis of GPI-Cp isoform protein. The values are normalized by $\beta$-actin protein level. All values are expressed as means $\pm \operatorname{SEM}(n=6)$. All indicated differences were statistically significant $(p<0.05)$. ${ }^{*} p \leq 0.05 ;{ }^{* *} p \leq 0.01$; ${ }^{* * *} p \leq 0.001$. Expression levels of control condition were normalized to one, and all values are expressed as relative units 

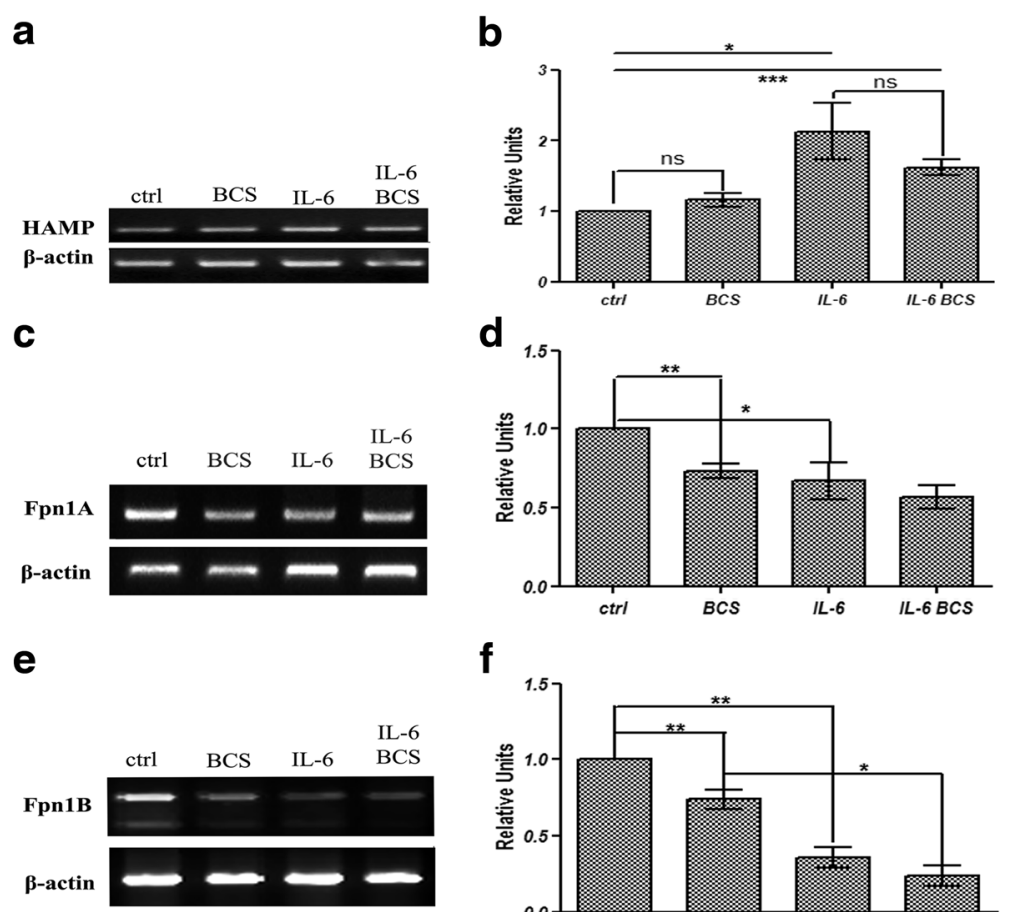

f
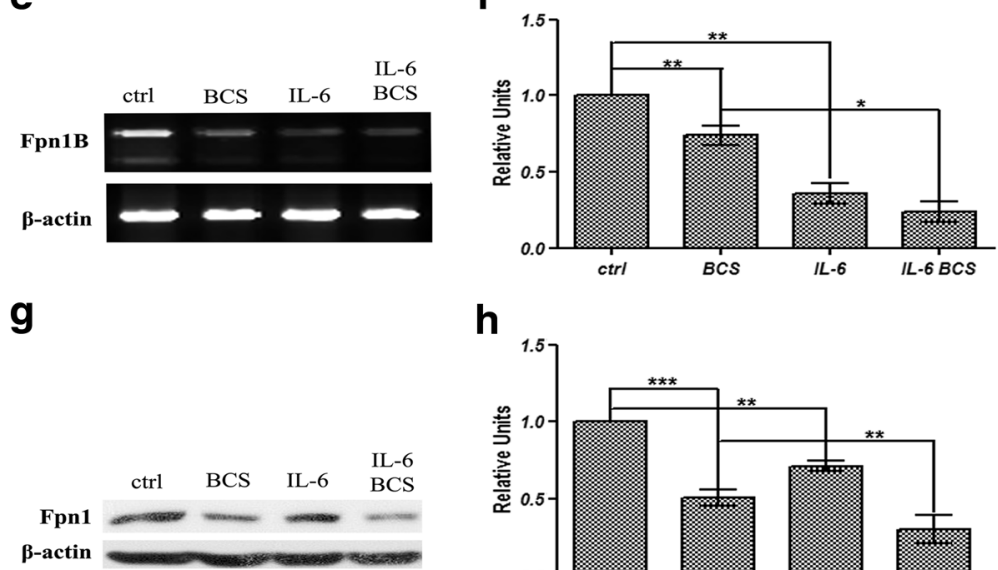

h

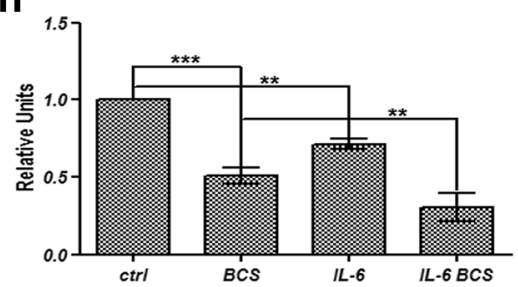

Fig. 3 RT-PCR analysis of HAMP gene, and RT-PCR and western blot analysis of Fpn1 expression levels. HepG2 cells were treated for $16 \mathrm{~h}$ in serum-free medium with $300 \mu \mathrm{M} \mathrm{BCS}$ and/or $40 \mathrm{ng} / \mathrm{ml} \mathrm{IL-6}$. a after $16 \mathrm{~h}$ of treatment, RNA was isolated, reverse transcribed and subjected to PCR. The amplicons relative to HAMP and $\beta$-actin genes were analysed by agarose gel electrophoresis and intensity of bands was determined by Image $1.47 \mathrm{~V}$ software (http://imagej.nih.gov/ij). The values of intensity relative to HAMP were normalized by using the $\beta$-actin housekeeping gene. $\mathbf{b}$ densitometric analysis of HAMP gene RT-PCR results (c) representative image of Fpn 1A isoform RT-PCR product analysed as described above and (d) densitometric analysis relative to Fpn IA RT-PCR results. The values were normalized by using the $\beta$-actin housekeeping gene. e representative image of Fpn $1 B$ isoform RT-PCR product analysed as described above and ( $\mathbf{f}$ ) densitometric analysis relative to Fpn1B RT-PCR results. The values were normalized by using the $\beta$-actin housekeeping gene. $\mathbf{g}$ representative image of Fpn1 protein immunoblot result relative to membrane proteins extracts. Equal amounts of proteins were loaded per lane. $\mathbf{h}$ densitometric analysis of Fpn1 protein. The values are normalized to $\beta$-actin protein level. All values are expressed as means \pm SEM $(n=6)$. All indicated differences were statistically significant $(p<0.05) .{ }^{*} p \leq 0.05 ;{ }^{* *} p \leq 0.01 ;{ }^{* *} p \leq 0.001$. Expression levels of control condition were normalized to one, and all values are expressed as relative units

\section{Effects of BCS and IL- 6 on TNF- $\alpha$ and IL- $1 \beta$ expression}

To test if the effect exerted by BCS alone or in combination with IL-6 was direct or indirect by production of other pro-inflammatory cytokines, the mRNA level of $T N F$-alpha and $I L-1 B$ was also assayed by qPCR. Unfortunately, the $C_{T}$ values relative to these two classes of mRNA were very low $\left(C_{T} 36-40\right)$ respect to $\beta$-actin mRNA level, and were not considered for further analysis.

\section{TfR1, and DMT1 expression}

Hepatocyte iron uptake through TfR1 and DMT1 is important in conditions of iron deficiency and it is also important under culture conditions in which the amount of iron is limited. For these reasons, the expression levels of these two proteins were investigated under copper chelation and proinflammation. Treatment of HepG2 cells with BCS resulted in a 50\% decrease in TfR1 protein levels (Fig. 4a and b) and IL- 6 had almost the same effect. Incubation of cells with both BCS and IL-6 led to a further decrease of TfR 1 indicating an additive effect. Given the functional relationship of TfR1 and DMT1 in TfR1-mediated iron uptake, the levels of DMT1 were also analysed. Incubation of HepG2 cells with BCS or IL-6 resulted in about a $50 \%$ decrement of 

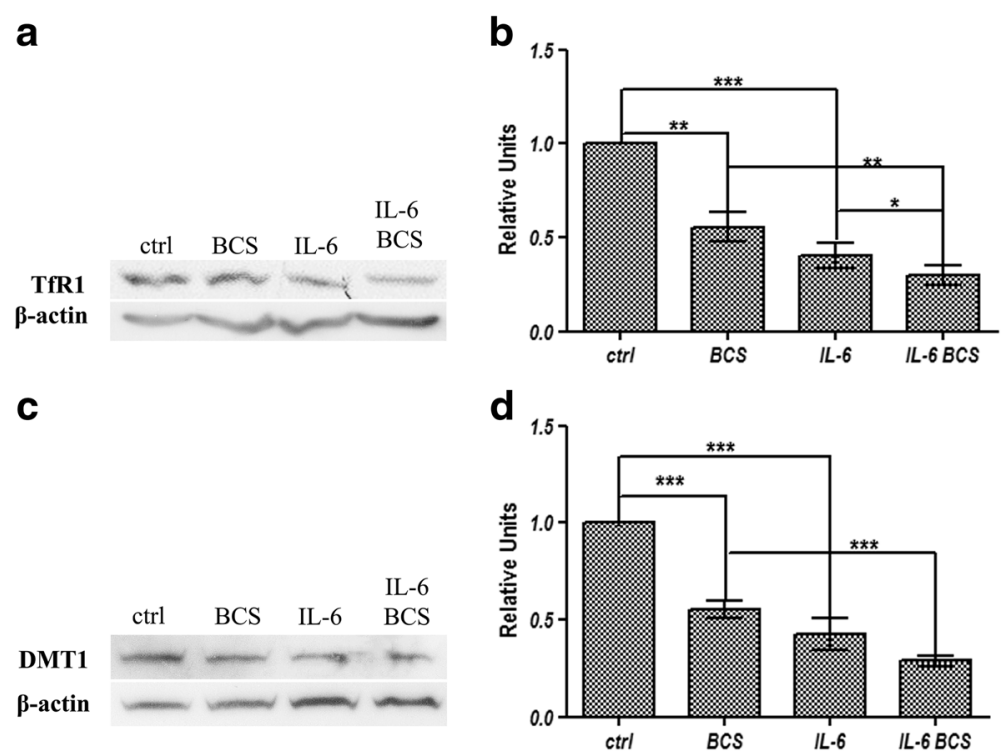

Fig. 4 Western blot analysis of TfR1, and DMT1. HepG2 cells were treated for $16 \mathrm{~h}$ in serum-free medium with $300 \mu \mathrm{M}$ BCS and/or $40 \mathrm{ng} / \mathrm{ml} \mathrm{IL-6.} \mathrm{a} \mathrm{representative} \mathrm{image} \mathrm{of} \mathrm{TfR1} \mathrm{protein} \mathrm{immunoblot} \mathrm{relative} \mathrm{to} \mathrm{membrane} \mathrm{proteins} \mathrm{exstracts.} \mathrm{Equal} \mathrm{amounts} \mathrm{of} \mathrm{proteins}$ were loaded per lane. $\mathbf{b}$ densitometric analysis of TfR1 protein. $\mathbf{c}$ representative image of DMT1 protein immunoblot relative to total cell extracts, after electrophoresis on 16.5\% Tris-Tricine SDS-PAGE (d) densitometric analysis of DMT1 protein. The values are normalized to $\beta$-actin. All values are expressed as means $\pm \operatorname{SEM}(n=6)$. All indicated differences were statistically significant $(p<0.05)$. ${ }^{*} p \leq 0.05 ;{ }^{* *} p \leq 0.01 ;{ }^{* * *} p \leq 0.001$. Expression levels of control condition were normalized to one, and all values are expressed as relative units

DMT1 protein, while treatment with both BCS and IL-6 led to an additional decrement, although it did not reach statistical significance (Fig. 4c, and d).

\section{FTH1 expression and cellular iron concentration}

To test if the experimental conditions affected intracellular iron level, we examined ferritin heavy chain (FTH1) protein levels, an indicator of cytosolic iron. The treatment of cells with IL-6 did not affect FTH1 levels. In contrast, BCS treatment resulted in an increase in FTH1 levels suggesting an increase of cellular iron content (Fig. 5a, and b). Further, the addition of IL-6 together with BCS increased FTH1 protein levels suggesting the intracellular iron levels are greatly increased in copper chelation and proinflammatory conditions. To exclude secondary effects, the cellular iron concentration was determined and, as shown in Fig. 5c, the concentration of iron is coherent with ferritin protein amounts, indicating that $\mathrm{BCS}$ is able to induce an increase of intracellular iron concentration.

\section{Discussion}

The copper-containing protein $\mathrm{Cp}$ has a key role in iron metabolism and its activity and level relies on appropriate copper acquisition. Accumulation of newly synthesized $\mathrm{Cp}$ is dependent on copper availability, as the stability of the apoprotein is severely reduced $[61,66,67]$. In Wilson Diseases caused by a mutation in $A T P 7 B$ gene, a Golgi copper transporter, $\mathrm{Cp}$ is produced in the apo-form that is secreted in the blood stream where it is rapidly degraded [68]. Decreased active $\mathrm{Cp}$ results in iron accumulation in liver and other organs due to a failure to export cellular iron [30-34]. Our study in the HepG2 cell line confirms that a deficiency of copper induces a strong reduction in the secreted form of $\mathrm{Cp}$. Treatment of cells with IL-6 led to a strong induction in $C p$ mRNA and protein levels, consistent with previously published data $[46,47,69]$. The IL-6 induction of $C p$ mRNA, however, was not able to reverse the negative effect on protein secretion exerted by BCS. Of interest is that our results showed that the presence of BCS had minimal influence on stability of GPI-Cp present on the plasma membrane; unfortunately, we were not able to demonstrate a linear correlation between the amount of protein present and its enzymatic activity. These data are in accord with Mostad et al. [14], who demonstrated that copper deficiency has different effects on GPI-Cp protein level in different organs. Copper deficiency in the spleen induces a strong decrement of GPI-Cp protein levels, while only a slight reduction of the protein was found in liver. The different response of the two $\mathrm{Cp}$ isoforms to a copper deprivation state could be explained by different kinetic of secretion or degradation rates of the apoprotein dependent on tissue type.

Our results suggest that copper deficiency has an effect on other proteins involved in iron metabolism. It is known that cellular export of Fe(II) by Fpn1 requires $\mathrm{Cp}$ to oxidize $\mathrm{Fe}^{2+}$ to $\mathrm{Fe}^{3+}$. Studies using transfected $\mathrm{C6}$ 

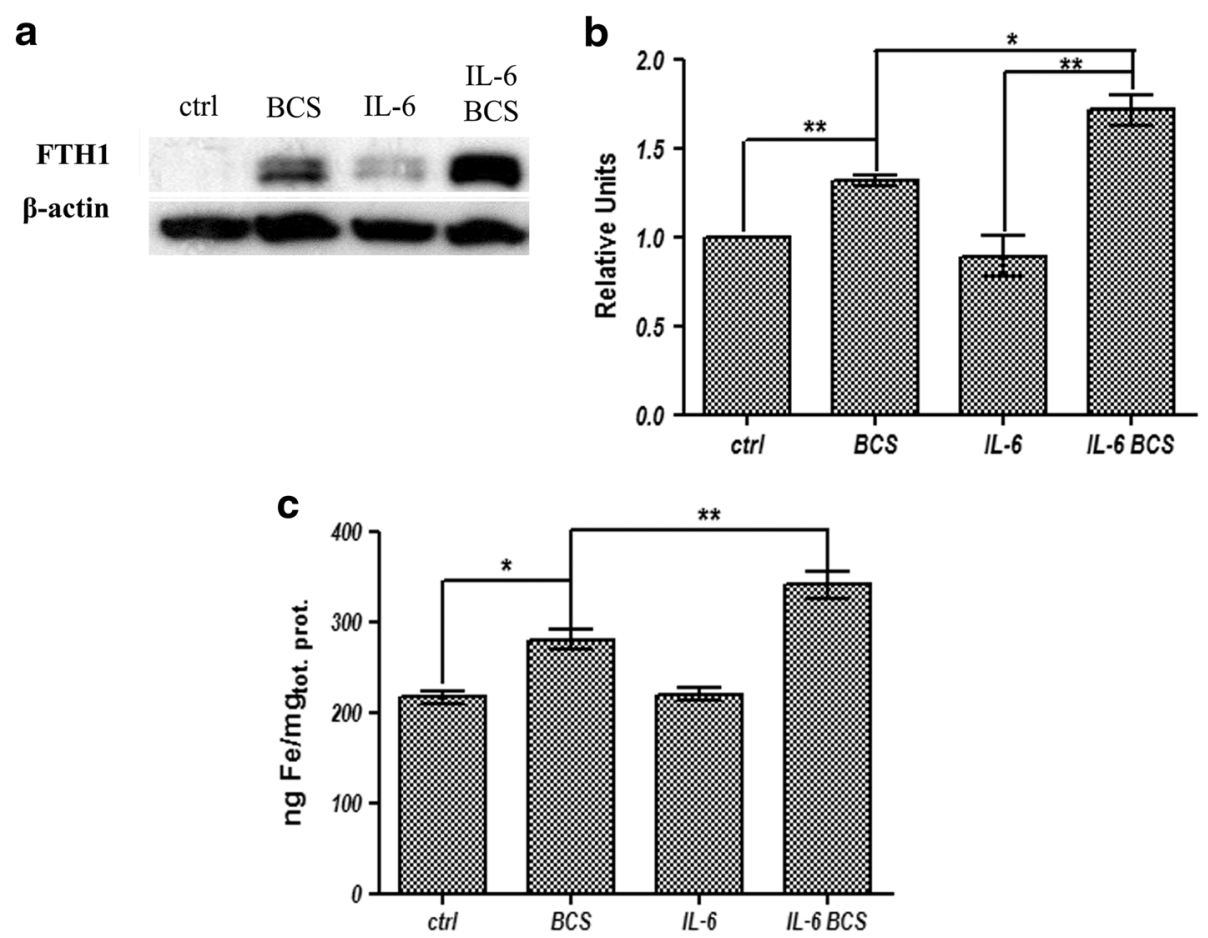

Fig. $5 \mathrm{FTH} 1$ expression levels and intracellular iron concentration. a representative image of FTH1 protein immunoblot relative to total cell extracts, after electrophoresis on 16.5\% Tris-Tricine SDS-PAGE. b densitometric analysis of FTH1 protein. The values are normalized to $\beta$-actin. $\mathbf{c}$ graph relative to intracellular iron concentration in HepG2 cells. Cells were extensively washed, lysed as described in methods, and used for atomic absorption analysis. The iron content was normalized by cellular total protein concentration. All values are expressed as means \pm SEM $(n=6)$. All indicated differences were statistically significant $(p<0.05)$. ${ }^{*} p \leq 0.05 ;{ }^{* *} p \leq 0.01 ;{ }^{* *} p \leq 0.001$. Expression levels of control condition were normalized to one, and all values are expressed as relative units

and HeLa cells showed that Cp activity is necessary for the stability of plasma membrane Fpn1 [63, 70,71], and an interaction between the two proteins was also hypothesized [62]. The results reported in this study highlight that Fpn1 is only partially influenced by GPICp protein amount; in fact, in conditions in which cells are treated with BCS, the decrement observed for Fpn1 protein is much more pronounced than that observed for GPI-Cp. This discrepancy can be explained considering the enzymatic activity rather than the protein amount. As mentioned, we do not know if the GPI-Cp protein present on the plasma membrane is also enzymatically active. A slight correlation is seen comparing Fpn1 and sCp protein amounts. The differences observed between our results and the reported published data could be explained with the use of different experimental models. In glioma cell lines the GPI-Cp is the isoform that is mostly highly expressed while in hepatocytes $\mathrm{sCp}$ is the most highly expressed isoform [11]. Different experimental models have reported some contrasting results such as animals fed a copper-deficient diet showed an increment of Fpn1 protein when whole liver was analysed. This apparent discrepancy could be due to a different response to the same stimuli between the different cells present in this organ, e.g., Kupffer cells and hepatocytes [14, 72, 73].

To determine if copper deficiency could affect Fpn1 levels by inducing hepcidin we assayed HAMP mRNA levels. In our cells, HAMP mRNA levels were not affected by copper chelation. In contrast, copper chelation affected Fpn1 transcripts including both Fpn1A and $F p n 1 B$ mRNA variants. To determine if the decrease observed was linked to a post-transcriptional regulation mechanism mediated by intracellular iron concentration, $\mathrm{H}$-ferritin subunit protein was assayed as a measure of cellular iron content. Our results showed increased levels of $\mathrm{H}$-ferritin suggesting an increase in cytosolic iron concentration. This result was confirmed by the determination of cellular iron concentration. Increased intracellular iron would be expected to increase Fpn 1 translation (IRP) and mRNA stability (mR485-3p), as increased Fpn1 activity is required to export cellular iron [74-76]. The finding that copper chelation leads to increased cellular iron retention and decreased Fpn1 mRNA suggests a novel mechanism of Fpn1 regulation. The response of HepG2 cell line to BCS is indicative of a state in which the cells protect themselves from the accumulation of intracellular iron, probably because a not 
functional ceruloplasmin could cause a condition of iron overload. For this reason, it is possible that in the first period of treatment, ferroportin is downregulated causing an increase of cellular iron concentration. As consequence, TfR1-mediated iron uptake is also reduced. Some studies have reported that hepcidin activity can be dependent on copper availability [77]; in fact, it has an "ATCUN" (amino-terminal Cu-Ni)-binding motif in the $\mathrm{N}$-terminal of the mature protein capable to bind copper and nickel, even if a recent study has questioning this possibility [77-79]. Tselepis et al. highlighted that the incapacity of hepcidin to bind copper, drastically reduce the capacity of hepcidin to induce ferroportin degradation [77]. Considering the results reported in this study and the possibility that hepcidin is not able to reduce ferroportin protein amount in condition of copper deficiency, a transcriptional downregulation of ferroportin can contrast a potential iron overload.

The apparent functional relationship between Fpn1 and $\mathrm{Cp}$ appears to break down in the face of inflammatory stimuli. $C p$ mRNA isoforms are strongly upregulated by IL-6, while Fpn1A and Fpn1B mRNAs seem to be downregulated. This effect is also seen on the protein level. The lower level of Fpn1 protein might be explained in part due to the post-translational hepcidinmediated degradation mechanism [41], as hepcidin is upregulated in inflammation [44]. Our data confirm that in HepG2 cells treatment with IL-6 strongly induces HAMP gene expression. However, independent of posttranslational regulation, our data show that IL- 6 reduces Fpn1 mRNA. These results are consistent with published data, which demonstrated that IL-6 is able to downregulate Fpn1 levels in the HepG2 cell line [48] and upregulate the mRNA level of $s C p[46,47]$. We demonstrate that the GPI-Cp isoform is also upregulated and the protein level of the two isoforms follow the same behaviour. The findings that IL- 6 results in increased Cp levels but decreased Fpn1 indicates that the functions of these two proteins are not obligatorily linked together. As mentioned above, it is reported that treatment with IL-6 causes an increase in Cp mRNA level, probably in part by the transcription factor FOXO1 [47]. This protein is involved in cellular response to oxidative stress and upregulation of $\mathrm{Cp}$ can enter in the mechanism of correlation between oxidative stress and metal metabolism [80, 81]; in fact, CP ferroxidase activity is important in the loading of $\mathrm{Fe}(\mathrm{III})$ on transferrin, reducing the deleterious effect of $\mathrm{Fe}(\mathrm{II})$ oxidation and production of radical oxygen species $[23,82]$. In this way, Cp enters in the circuit to limit NTBI (non-transferrin bound iron) in the serum with hepcidin that is strongly upregulated in IL-6 induced inflammation and, with its activity, limits the presence of iron in the plasma [43]. In addition to ferroxidase activity, $\mathrm{Cp}$ has other functions as $\mathrm{Cu}(\mathrm{I})$ oxidation [83], $\mathrm{NO}$-oxidase and $\mathrm{NO}_{2}^{-}$synthase [84], and superoxide dismutase [85]. Moreover, an interaction between $\mathrm{Cp}$ and myeloperoxidase (MPO) was also demonstrated and it is supposed that $\mathrm{Cp}$ inhibits prooxidant activity of MPO [86]; in fact, in systemic vasculitis, the interaction between $\mathrm{Cp}$ and MPO is prevented by autoantibodies against MPO [87]. In vitro experiments have highlighted an interaction between $\mathrm{Cp}$, MPO and lactoferrin (Lf). This ternary complex has different functions as reduce the activity of MPO, incorporate $\mathrm{Fe}(\mathrm{III})$ on Lf and protect $\mathrm{Cp}$ from proteolytic cleavage [88]. For these reasons, $\mathrm{Cp}$ can have a fundamental role in inflammation conditions and in autoimmunity diseases.

The dysfunction of cellular iron export resulting from copper chelation has an effect on TfR1-mediated iron delivery, resulting in decreased expression of TfR 1 and DMT1. These results are consistent with published studies in which copper deficiency led to a decrement in TfR1 protein in the liver $[73,89]$.

\section{Conclusions}

In summary, here we have demonstrated, using a hepatoma cell line, that IL- 6 results in increased Cp levels and decreased Fpn1, indicating that the functions of these two proteins are not obligatorily linked together.

Moreover, we have demonstrated that copper chelation has effects not only on $\mathrm{Cp}$ but also on other proteins involved in iron metabolism, sometimes at the mRNA level.

\section{Acknowledgement}

We are grateful for the critical reading, manuscript editing, and precious suggestions to prof. Jerry Kaplan and prof. Diane McVey Ward of the University of Utah.

\section{Funding}

We thank, for their financial support, prof. A. Mastino (Grant sponsor: Italian Ministry for Education, University and Research, Research Project of National Interest; funding reference number: 2012SNMJRL_004), and prof. S. Cuzzocrea (Grant sponsor: Italian Ministry for Education, University and Research, Research Project of National Interest; funding reference number: 2012WBSSY4_003) of the Department of Chemical, Biological, Pharmaceutical, and Environmental Sciences, University of Messina.

\section{Availability of data and materials \\ The datasets generated and/or analysed during the current study are available from the corresponding author on reasonable request.}

\section{Authors' contributions}

LMB performed the biological experiments, participated in the interpretation of data, and revised manuscript. RA, and FB, performed the biological experiments. GT performed the atomic absorption spectroscopy analysis. MRF designed the experiments, interpreted the data, and wrote the manuscript. All the authors read and approved the final manuscript.

Competing interests

The authors declare that they have no competing interests.

Consent for publication

Not applicable.

Ethics approval and consent to participate Not applicable. 


\section{Author details}

'Department of Chemical, Biological, Pharmaceutical, and Environmental Sciences, University of Messina, Viale F. Stagno D'Alcontres, 31, 98166 Messina, Italy. ${ }^{2}$ Inter University National Group of Marine Sciences (CoNISMa), Piazzale Flaminio, 9, 00196 Rome, Italy.

Received: 25 August 2016 Accepted: 9 January 2017

Published online: 24 January 2017

\section{References}

1. Aust SD, Morehouse LA, Thomas CE. Role of metals in oxygen radical reactions. Free Radic Biol Med. 1985;1:3-25.

2. Halliwell B. Oxidative DNAS damage: meaning and measurement. In: Halliwell B, Aruoma Ol, editors. DNA and free radicals. Chichester: Ellis Horwood Ltd; 1993. p. 67-79.

3. Stadtman ER. Metal ion-catalyzed oxidation of proteins: biochemical mechanism and biological consequences. Free Radic Biol Med. 1990; 9(4):315-25

4. Frieden E, Hsieh HS. Ceruloplasmin: the copper transport protein with essential oxidase activity. Adv Enzymol Relat Areas Mol Biol. 1976;44: 187-236.

5. Lindley PF, Card G, Zaitseva I, Zaitsev V, Reinhammar B, Selin-Lindgren E, et al. An X-ray structural study of human ceruloplasmin in relation to ferroxidase activity. J Biol Inorg Chem. 1997;2:454-63.

6. Bento I, Peixoto C, Zaitzev VN, Lindley PF. Ceruloplasmin revisited: structural and functional roles of various metal cation-binding sites. Acta Crystallogr D Biol Crystallogr. 2007;63(2):240-8.

7. Yang FM, Friedrichs WE, Cupples RL, Bonifacio MJ, Sanford JA, Horton WA, et al. Human ceruloplasmin. Tissue specific expression of transcripts produced by alternative splicing. J Biol Chem. 1990;265:10780-5.

8. Healy J, Tipton K. Ceruloplasmin and what it might do. J Neural Transm. 2007;114:777-81.

9. Ortel TL, Takahashi N, Putnam FW. Structural model of human ceruloplasmin based on internal triplication, hydrophilic/hydrophobic character, and secondary structure of domains. Proc Natl Acad Sci U S A. 1984;81(15):4761-5.

10. Patel BN, David S. A novel glycosylphosphatidylinositol-anchored form of ceruloplasmin is expressed by mammalian astrocytes. J Biol Chem. 1997;272:20185-90.

11. Patel BN, Dunn RJ, David S. Alternative RNA splicing generates a glycosylphosphatidylinositol-anchored form of ceruloplasmin in mammalian brain. J Biol Chem. 2000;275(6):4305-10.

12. Fortna RR, Watson HA, Nyquist SE. Glycosyl phosphatidylinositolanchored ceruloplasmin is expressed by rat Sertoli cells and is concentrated in detergent-insoluble membrane fractions. Biol Reprod. 1999;61:1042-9.

13. Mittal B, Doroudchi MM, Jeong SY, Patel BN, David S. Expression of a membrane-bound form of the ferroxidase ceruloplasmin by leptomeningeal cells. Glia. 2003:41(4):337-46.

14. Mostad EJ, Prohaska JR. Glycosylphosphatidylinositol-linked ceruloplasmin is expressed in multiple rodent organs and is lower following dietary copper deficiency. Exp Biol Med. 2011;236(3):298-308.

15. Marques L, Auriac A, Willemetz A, Banha J, Silva B, Canonne-Hergaux F, et al. Immune cells and hepatocytes express glycosylphosphatidylinositolanchored ceruloplasmin at their cell surface. Blood Cells Mol Dis. 2012:48(2):110-20.

16. Vulpe CD, Kuo YM, Murphy TL, Cowley L, Askwith C, Libina N, et al. Hephaestin, a ceruloplasmin homologue implicated in intestinal iron transport, is defective in the sla mouse. Nat Genet. 1999;21:195-9.

17. Frazer DM, Vulpe CD, McKie AT, Wilkins SJ, Trinder D, Cleghorn GJ, et al. Cloning and gastrointestinal expression of rat hephaestin: relationship to other iron transport proteins. Am J Physiol Gastrointest Liver Physiol. 2001;281:G931-9.

18. Ganz T. Cellular iron: ferroportin is the only way out. Cell Metab. 2005; 1:155-7.

19. Donovan A, Brownlie A, Zhou Y, Shepard J, Pratt SJ, Moynihan J, et al. Positional cloning of zebrafish ferroportin 1 identifies a conserved vertebrate iron exporter. Nature. 2000;403:776-81.

20. Han O, Kim EY. Colocalization of ferroportin-1 with hephaestin on the basolateral membrane of human intestinal absorptive cells. J Cell Biochem. 2007;101:1000-10
21. Yeh KY, Yeh M, Glass J. Interactions between ferroportin and hephaestin in rat enterocytes are reduced after iron ingestion. Gastroenterology. 2011;141:292-9.

22. Yeh KY, Yeh M, Mims L, Glass J. Iron feeding induces ferroportin 1 and hephaestin migration and interaction in rat duodenal epithelium. Am J Physiol Gastrointest Liver Physiol. 2009;296:G55-65.

23. Roeser HP, Lee GR, Nacht S, Cartwright GE. The role of ceruloplasmin in iron metabolism. J Clin Invest. 1970;49:2408-17.

24. Jandl JH, Inman JK, Simmons RL, Allen DW. Transfer of iron from serum iron-binding protein to human reticulocytes. J Clin Invest. 1959;38:161-85.

25. Morgan EH, Appleton TC. Autoradiographic localization of 125-I-labelled transferrin in rabbit reticulocytes. Nature. 1969;223:1371-2.

26. Van Renswoude J, Bridges KR, Harford JB, Klausner RD. Receptor-mediated endocytosis of transferrin and the uptake of Fe in K562 cells: identification of a nonlysosomal acidic compartment. Proc Natl Acad Sci U S A. 1982;79: 6186-90.

27. Dautry-Varsat A, Ciechanover A, Lodish HF. pH and the recycling of transferrin during receptor-mediated endocytosis. Proc Natl Acad Sci U S A. 1983;80:2258-62.

28. Conner SD, Schmid SL. Differential requirements for AP-2 in clathrinmediated endocytosis. J Cell Biol. 2003;162:773-9.

29. Frazer DM, Anderson GJ. Iron imports. I. Intestinal iron absorption and its regulation. Am J Physiol Gastrointest Liver Physiol. 2005;289:G631-5.

30. Yoshida K, Furihata K, Takeda S, Nakamura A, Yamamoto K, Morita H, et al. A mutation in the ceruloplasmin gene is associated with systemic hemosiderosisin humans. Nat Genet. 1995;9(3):267-72.

31. Harris ZL, Durley AP, Man TK, Gitlin JD. Targeted gene disruption reveals an essential role for ceruloplasmin in cellular iron efflux. Proc Natl Acad Sci U S A. 1999;96:10812-7.

32. Panagiotakaki E, Tzetis M, Manolaki N, Loudianos G, Papatheodorou A, Manesis $E$, et al. Genotype-phenotype correlations for a wide spectrum of mutations in the Wilson disease gene (ATP7B). Am J Med Genet A. 2004; 131(3):168-73.

33. Hayashi H, Yano M, Fujita Y, Wakusawa S. Compound overload of copper and iron in patients with Wilson's disease. Med Mol Morphol. 2006;39(3):121-6.

34. Kodama H, Fujisawa C. Copper metabolism and inherited copper transporter disorders: molecular mechanisms, screening, and treatment. Metallomics. 2009;1:42-52.

35. Torsdottir G, Kristinsson J, Sveinbjornsdottir S, Snaedal J, Jóhannesson T. Copper, ceruloplasmin, superoxide dismutase and iron parameters in Parkinson's disease. Pharmacol Toxicol. 1999;85(5):239-43.

36. Jin L, Wang J, Zhao L, Jin H, Fei G, Zhang Y, Zeng M, Zhong C. Decreased serum ceruloplasmin levels characteristically aggravate nigral iron deposition in Parkinson's disease. Brain. 2011;134(1):50-8.

37. Kristinsson J, Snaedal J, T rsd ttir G, J hannesson T. Ceruloplasmin and iron in Alzheimer's disease and Parkinson's disease: a synopsis of recent studies. Neuropsychiatr Dis Treat. 2012;8:515-21.

38. Ayton S, Lei P, Duce JA, Wong BX, Sedjahtera A, Adlard PA, et al. Ceruloplasmin dysfunction and therapeutic potential for Parkinson's disease. Ann Neurol. 2013;73(4):554-9.

39. Weiss G. Modification of iron regulation by the inflammatory response. Best Pract Res Clin Haematol. 2005:18:183-201.

40. Ganz T. Hepcidin, a key regulator of iron metabolism and mediator of anemia of inflammation. Blood. 2003;102(3):783-8.

41. Nemeth E, Tuttle MS, Powelson J, Vaughn MB, Donovan A, Ward DM, Ganz T, Kaplan J. Hepcidin regulates cellular iron efflux by binding to ferroportin and inducing its internalization. Science. 2004;306:2090-3.

42. Nemeth $\mathrm{E}, \mathrm{Ganz} \mathrm{T}$. The role of hepcidin in iron metabolism. Acta Haematol. 2009;122(2-3):78-86

43. Nemeth E, Valore EV, Territo M, Schiller G, Lichtenstein A, Ganz T. Hepcidin, a putative mediator of anemia of inflammation, is a type II acute-phase protein. Blood. 2003;101(7):2461-3.

44. Nemeth E, Rivera S, Gabayan V, Keller C, Taudorf S, Pedersen BK, Ganz T. IL-6 mediates hypoferremia of inflammation by inducing the synthesis of the iron regulatory hormone hepcidin. J Clin Invest. 2004;113(9):1271-6.

45. Ganz T, Nemeth E. Iron sequestration and anemia of inflammation. Semin Hematol. 2009:46(4):387-93.

46. Conley L, Geurs TL, Levin LA. Transcriptional regulation of ceruloplasmin by an IL-6 response element pathway. Brain Res Mol Brain Res. 2005;139:235-41.

47. Sidhu A, Miller PJ, Hollenbach AD. FOXO1 stimulates ceruloplasmin promoter activity in human hepatoma cells treated with IL-6. Biochem Biophys Res Commun. 2011;404:963-7. 
48. Naz N, Malik IA, Sheikh N, Ahmad S, Khan S, Blaschke M, et al. Ferroportinis a 'nuclear'-negative acute-phase protein in rat liver: a comparison with other iron-transport proteins. Lab Invest. 2012;92(6):842-56.

49. Ahmad S, Sultan S, Naz N, Ahmad G, Alwahsh SM, Cameron S, et al. Regulation of iron uptake in primary culture rat hepatocytes: the role of acute-phase cytokines. Shock. 2014;41(4):337-45.

50. Tacchini L, Gammella E, De Ponti C, Recalcati S, Cairo G. Role of HIF-1 and NF-kappaB transcription factors in the modulation of transferrin receptor by inflammatory and anti-inflammatory signals. J Biol Chem. 2008;283(30): 20674-86.

51. Fein $E$, Merle $U$, Ehehalt $R$, Herrman $T$, Kulaksiz $H$. Regulation of hepcidin in HepG2 and RINm5F cells. Peptides. 2007;28(5):951-7.

52. Livak KJ. ABI Prism 7700 Sequence detection System User Bulletin \#2 Relative quantification of gene expression; 1997 \& 2001. http://docs. appliedbiosystems.com/pebiodocs/04303859.pdf.

53. Livak KJ, Schmittgen TD. Analysis of relative gene expression data using real-time quantitative $P C R$ and the $2 \wedge$ [-delta delta $C(T)]$ Method. Methods. 2001;25(4):402-8.

54. Schägger $H$, von Jagow $G$. Tricine-sodium dodecyl sulfate polyacrylamide gel electrophoresis for the separation of proteins in the range from 1-100 kDalton. Anal Biochem. 1987;166:368-79.

55. Delaby C, Pilard N, Gonçalves AS, Beaumont C, Canonne-Hergaux F. Presence of the iron exporter ferroportin at the plasma membrane of macrophages is enhanced by iron loading and down-regulated by hepcidin. Blood. 2005;106(12):3979-84.

56. Delaby C, Pilard N, Puy H, Canonne-Hergaux F. Sequential regulation of ferroportin expression after erythrophagocytosis in murine macrophages: early mRNA induction by haem, followed by iron-dependent protein expression. Biochem J. 2008:411:123-31.

57. Vazquez MC, Martınez P, Alvarez AR, Gonzalez M, Zanlungo S. Increased copper levels in in vitro and in vivo models of Niemann-Pick $C$ disease. Biometals. 2012;25:777-86.

58. di Patti Bonaccorsi MC, Bellenchi GC, Bielli P, Calabrese L. Release of highly active Fet3 from membranes of the yeast Pichia pastoris by limited proteolysis. Arch Biochem Biophys. 1999;372:295-9.

59. Heinrich PC, Behrmann I, Haan S, Hermanns HM, Muller-Newen G, Schaper F. Principles of interleukin (IL)-6-type cytokine signalling and its regulation. Biochem J. 2003;374(1):1-20.

60. Levy DE, Darnell Jr JE. Stats: transcriptional control and biological impact. Nat Rev Mol Cell Biol. 2002;3(9):651-62.

61. Gitlin JD, Schroeder JJ, Lee-Ambrose LM, Cousins RJ. Mechanisms of caeruloplasmin biosynthesis in normal and copper-deficient rats. Biochem J. 1992;282:835-9.

62. Jeong SY, David S. Glycosylphosphatidylinositol-anchored ceruloplasminis required for iron efflux from cells in the central nervous system. J Biol Chem. 2003;278(29):27144-8

63. Bonaccorsi di Patti MC, Maio N, Rizzo G, De Francesco G, Persichini T, Colasanti $M$, et al. Dominant mutant of ceruloplasmin impair the copper loading machinery in aceruloplasminemia. J Biol Chem. 2009;284(7):4545-54

64. Cianetti L, Segnalini P, Calzolari A, Morsilli O, Felicetti F, Ramoni C, et al. Expression of alternative transcripts of ferroportin-1 during human erythroid differentiation. Haematologica. 2005;90:1595-606.

65. Zhang DL, Hughes RM, Ollivierre-Wilson H, Ghosh MC, Roualt TA. A Ferroportin transcript that lack an iron responsive element enables duodenal and erythroid precursor cells to evade translational repression. Cell Metab. 2009;9(5):461-73.

66. Holtzman NA, Gaumnitz BM. Identification of an apoceruloplasmin-like substance in the plasma of copper-deficient rats. J Biol Chem. 1970;245(9): 2350-3.

67. Broderius M, Mostad E, Wendroth K, Prohaska JR. Levels of plasma ceruloplasmin protein are markedly lower following dietary copper deficiency in rodents. Comp Biochem Physiol C Toxicol Pharmacol. 2010;151(4):473-9.

68. Huster D, Finegold MJ, Morgan CT, Burkhead JL, Nixon R, Vanderwerf SM, et al. Consequences of copper accumulation in the livers of Atp7b-/- Wilson disease gene) knockout mice. Am J Pathol. 2006;168(2):423-34.

69. McCarthy RC, Kosman DJ. Activation of C6 glioblastoma cell ceruloplasmin expression by neighboring human brain endothelia-derived interleukins in an in vitro blood-brain barrier model system. Cell Commun Signal. 2014;12:65.
70. De Domenico I, Ward DM, Di Patti Bonaccorsi MC, Jeong SY, David S, Musci G, et al. Ferroxidase activity is required for the stability of cell surface ferroportin in cells expressing GPI-ceruloplasmin. EMBO J. 2007;26(12):2823-31.

71. Kono S, Yoshida K, Tomosugi N, Terada T, Hamaya Y, Kanaoka S, et al. Biological effects of mutant ceruloplasmin on hepcidin-mediated internalization of ferroportin. Biochim Biophys Acta. 2010;1802(11):968-75.

72. Jenkitkasemwong S, Broderius M, Nam H, Prohaska JR, Knutson MD. Anemic copper-deficient rats, but not mice, display low hepcidin expression and high ferroportin levels. J Nutr. 2010;140(4):723-30.

73. Broderius M, Mostad E, Prohaska JR. Suppressed hepcidin expression correlates with hypotransferrinemia in copper-deficient rat pups but not dams. Genes Nutr. 2012;7(3):405-14.

74. Muckenthaler MU, Galy B, Hentze MW. Systemic iron homeostasis and the iron-responsive element/iron-regulatory protein (IRE/IRP) regulatory network. Annu Rev Nutr. 2008:28:197-213.

75. Lymboussaki A, Pignatti E, Montosi G, Garuti C, Haile DJ, Pietrangelo A. The role of the iron responsive element in the control of ferroportin1/IREG1/ MTP1 gene expression. J Hepatol. 2003;39:710-5.

76. Sangokoya C, Doss JF, Chi JT. Iron-responsive miR-485-3p regulates cellular iron homeostasis by targeting ferroportin. PLoS Genet. 2013;9(4):1-11.

77. Tselepis C, Ford SJ, McKie AT, Vogel W, Zoller H, Simpson RJ, Castro JD, lqbal TH, Ward DG. Characterization of the transition-metal binding properties of hepcidin. Biochem J. 2010;427:289-96.

78. Melino S, Garlando L, Patamia M, Paci M, Petruzzelli R. A metal-binding site is present in the amino terminal region of the bioactive iron regulator hepcidin-25. J Pept Res. 2005;66:65-71.

79. Kulprachakarn K, Chen YL, Kong X, Arno MC, Hider RC, Srichairatanakool S, et al. Copper(II) binding properties of hepcidin. J Biol Inorg Chem. 2016;21:329-38

80. Walter PL, Steinbrenner H, Barthel A, Klotz LO. Stimulation of selenoprotein P promoter activity in hepatoma cells by FoxO1a transcription factor. Biochem Biophys Res Commun. 2008;365:316-21.

81. de Candia P, Blekhman R, Chabot AE, Oshlack A, Gilad Y. A combination of genomic approaches reveals the role of FOXO1a in regulating an oxidative stress response pathway. PLoS ONE. 2008;3(2):e1670.

82. Bielli $P$, Calabrese L. Structure to function relationships in ceruloplasmin: a moonlighting protein. Cell Mol Life Sci. 2002;59:1413-27.

83. Stoj C, Kosman DJ. Cuprous oxidase activity of yeast Fet $3 p$ and human ceruloplasmin: implication for function. FEBS Lett. 2003;554:422-6.

84. Shiva S, Wang X, Ringwood LA, Xu X, Yuditskaya S, et al. Ceruloplasmin is a NO oxidase and nitrite synthase that determines endocrine NO homeostasis. Nat Chem Biol. 2006:2:486-93.

85. Vasil'ev VB, Kachurin AM, Soroka NV. Dismutation of superoxide radicals by ceruloplasmin - details of the mechanism. Biokhimiia. 1988:53:2051-8.

86. Segelmark M, Persson B, Hellmark T, Wieslander J. Binding and inhibition of myeloperoxidase (MPO): a major function of ceruloplasmin? Clin Exp Immunol. 1997;108:167-74.

87. Griffin SV, Chapman PT, Lianos EA, Lockwood CM. The inhibition of myeloperoxidase by ceruloplasmin can be reversed by antimyeloperoxidase antibodies. Kidney Int. 1999;55:917-25.

88. Samygina VR, Sokolov AV, Bourenkov G, Petoukhov MV, Pulina MO, Zakharova ET, et al. Ceruloplasmin: macromolecular assemblies with ironcontaining acute phase proteins. PLoS ONE. 2013;8(7):e67145.

89. Chung J, Prohaska JR, Wessling-Resnick M. Ferroportin-1 is not upregulated in copper-deficient mice. J Nutr. 2004;134(3):517-21.

90. Banha J, Marques L, Oliveira R, Martis Mde F, Paixao E, Pereira D, et al. Ceruloplasmin expression by human peripheral blood lymphocytes: a new link between immunity and iron metabolism. Free Radic Biol Med. 2008;44(3):483-92. 